\title{
JNPH
}

Volume 7 No. 1 (April 2019)

(C) The Author(s) 2019

\section{EFEKTIFITAS PEMBERIAN SALEP KULIT GENTAMICYN TERHADAP PENYEMBUHAN LUKA PADA PASIEN DIABETES MELLITUS \\ DI WILAYAH KERJA PUSKESMAS BERINGIN RAYA KOTA BENGKULU TAHUN 2018}

\author{
EFFECTIVENESS OF GIVING GENTAMICYN SKIN ON WOUND HEALING IN \\ PATIENTS OF DIABETES MELLITUS IN THE WORKING AREA \\ OF A BERINGIN RAYA COMMUNITY HEALTH CENTERS \\ BENGKULU CITY IN 2018
}

\author{
EMILIA \\ PUSKESMAS BERINGIN RAYA \\ Email: emilia090882@gmail.com
}

\begin{abstract}
ABSTRAK
Pasien Infeksi ulkus kaki diabetik memerlukan penggunaan salep kulit gentamicyn, salep kulit gentamicyn yang sering digunakan mempunyai sensitifitas rendah dan beberapa pasien pada penggunaannya dalam keadaan resistensi, evaluasi efektifitas salep kulit gentamicyn perlu dilakukan untuk mengatasi masalah luka Diabetik grade I dan II saat ini agar tidak berlanjut ke grade berikutnya. Penelitian ini dilakukan dengan studi longitudinal dan teknik pengambilan sampel secara prospektif. Paramater yang diamati adalah keadaan leukosit, tanda infeksi dan demam seteleh pemberian salep kulit gentamicyn. Data yang terkumpul kemudian dianalisis secara deskriptif untuk menentukan efektifitas salep kulit gentamicyn berdasarkan literatur yang mendukung. Hasil perolehan sampel pada penelitian ini adalah sebanyak 19 sampel pasien infeksi ulkus kaki diabetik yang memenuhi kriteria dari 28 orang populasi terdiri dari $63,16 \%$ pasien laki-laki dan 36,84\% pasien perempuan, 68,42 \% usia 45-60 tahun dan lama diabetes terbanyak adalah $>10$ tahun. Hasil evaluasi efektifitas salep kulit gentamicyn yaitu ditemukan 8 orang pasien yang menggunakan salep kulit gentamicyn secara dugaan (empiris) dan 11 orang pasien menggunakan salep kulit gentamicyn berdasarkan sensitifitas (definitif). salep kulit gentamicyn efektif pada 15 orang subjek penelitian yaitu dapat memberikan respon pada leukosit, tanda infeksi dan parameter demam seteleh pemberian salep kulit gentamicyn 2-3 hari dan hasil terapi maksimal pada hari ke 7 sampai 21.
\end{abstract}

Kata Kunci: infeksi; kaki diabetes; ulkus; salep kulit gentamicyn; efektifitas

\begin{abstract}
Patients with diabetic foot infection require gentamicyn skin ointment. Generally, gentamicyn skin ointment may have low sensitivity and some bacteria have been resistance to gentamicyn skin ointment. Currently, evaluation of the effectiveness of gentamicyn skin ointment needs to be done to overcome the current problems of grade Iand II lyla diabetic so as not to continue the next grde. gentamicyn skin ointment resistance. This study has been conducted using the longitudinal method and prospective sampling technique. Observed parameters were leukocyte,
\end{abstract}


signs of infection and fever after using gentamicyn skin ointment. The data collected were then analyzed to determine the effectiveness of gentamicyn skin ointment based on supporting literature. A number of 19 out of 28 samples of patients with diabetic foot ulcer met the criteria, consisting of $63.16 \%$ and $36.84 \%$ of male and female patients, respectively. Most of the patients $(68,42 \%)$ were aged 45-60 years old living with diabetes for more than 10 years. gentamicyn skin ointment therapy were given empirically in 8 patients $(42,10 \%)$ and based on gentamicyn skin ointment sensitivity (definitive) in 11 patients $(57,89 \%)$. The use of gentamicyn skin ointment was effective in 15 patients $(78,94 \%)$ marked by the leukocyte count, signs of infection and fever parameters after 2-3 days using gentamicyn skin ointment. The optimum therapeutic outcome was achieved in 7 to 21 days.

\section{Keywords: infection; diabetic foot; ulcers; gentamicyn skin ointment; effectiveness}

\section{PENDAHULUAN}

Sekitar $\quad 80 \% \quad$ kematian pada penderita diabetes millitus (DM) disebabkan oleh trombosis. Daerah yang sering mengalami trombosis pada penderita DM adalah pada pembuluh darah daerah ekriminitas bawah bagian distal. Terjadinya trombosis akan mengganggu suplai darah ke daerah luka sehingga akan menghambat proses penyembuhan luka dan menyebabkan terjadinya ulkus.

Ulkus kaki diabetik merupakan suatu komplikasi diabetes yang perlu mendapatkan perhatian khusus.. Berdasarkan studi pendahuluan, beberapa pasien infeksi ulkus kaki diabetik mengalami penyembuhan yang lama terhadap luka secara mikrobiologis. Salah satu cara untuk meminimalkan perluasan infeksi adalah teknik perawatan pembersihan ulkus diabetik dengan penggunaan salep kulit gentamicyn.

Menurut penelitian Decroli tentang profil ulkus diabetik dan penelitian Hatanta tentang kajian penggunaan Antibiotik, pada pasien infeksi ulkus kaki diabetik di Puskesmas Beringin Raya beberapa bakteri tidak mempan terhadap salaf kulit lainya yang digunakan secara empiris seperti oxytetra, bacitracin, dan lainya. Penggunaan Salep kulit secara tidak tepat mengakibatkan tujuan terapi tidak tercapai dan terjadinya proses penyembuhan yang lama dan bisa berlanjut ke grade berikutnya. Resistensi ini menyebabkan dibutuhkannya cara perawatan dan pengobatan baru untuk mengatasi infeksi yang lama. Namun, proses yang dilakukan untuk menemukan cara perawatan dan pengobatan baru dan melanjutkan terapi yang efektif membutuhkan waktu yang lama dan biaya yang besar.

Penelitian ini bertujuan untuk monitoring respon terapi pada pasien infeksi ulkus kaki diabetik grade Idan II setelah pemberian salep kulit gentamicyn . Efektifitas salep kulit gentamicyn pada luka kaki diabetik dapat dilihat dari adanya perbaikan tanda klinis dan perbaikan hasil laboratorium.

\section{METODE PENELITIAN}

Penelitian ini merupakan penelitian deskriptif dimana pengumpulan data dilakukan secara prospektif melalui penelusuran terhadap kondisi pasien dan catatan rekam medik. Efektifitas salep kulit gentamicyn ditentukan berdasarkan literatur yang mendukung. Populasi adalah semua pasien infeksi luka kaki diabetik yang berada di wilayah kerja Puskesmas beringin Raya Kota Bengkulu. Sampel yang diambil adalah pasien luka diabetes mellitus Grade I dan II yang menerima Salep kulit Genta micyn yang memenuhi kriteria inklusi.

\section{Kriteria sampel}

Data inklusi sampel yang dipilih adalah pasien luka diabetik grade I dan II yang menggunakan Salep kulit Gentamicyn. Data ekslusi pasien rawat Jalan yang berobat ke Poli Umum Puskesmas Perawatan Bernigin 
Raya yang diamati melalui kunjungan pasien dan kunjungan berikutnya serta kunjungan Petugas ke Rumah Pasien.

Protokol penelitian

Pengumpulan data berupa jumlah pasien, jenis kelamin, umur, diagnosa penyakit, salep kulit gentamicyn yang digunakan, klasifikasi grade ulkus diabetik, tanda vital (suhu tubuh), kadar gula darah, jumlah tanda-tanda inflamasi (kalor, tumor, dolor, rubor, fungsio laesa) dan pus. Data diperoleh dari rekam medik, catatan perawat, dan observasi langsung. Katagori pengamatan efektifitas meliputi perbaikan jaringan luka, penurunan suhu tubuh, dan perbaikan tanda inflamasi setelah penggunaan salep gentamicyn.

Pengolahan dan analisis data

Data diperoleh dari rekam medik, catatan perawat, dan observasi langsung kemudian dikumpulkan dalam lembar data. Data yang telah terkumpul kemudian dianalisis secara deskriptif non analitik untuk menentukan efektifitas antibiotik berdasarkan literatur yang mendukung yang digambarkan dalam bentuk tabel dan diagram.

\section{HASIL}

Tabel 1. Data profil subjek penelitian

\begin{tabular}{|cc|}
\hline Karakteristik Pasien & Jumlah (\%) \\
\hline Jenis kelamin & 63,16 \\
Laki-laki & 36,84 \\
Perempuan & \\
Usia & 15,78 \\
$<45$ th & 68,42 \\
$45-60$ th & 15,78 \\
\hline >60th & \\
\hline
\end{tabular}

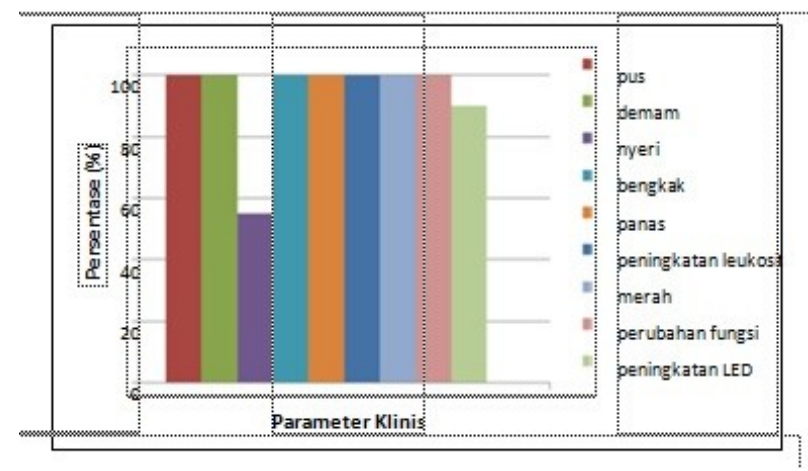

\section{Gambar 1. Parameter klinis tanda-tanda infeksi pada pasien}

Berdasarkan data yang diperoleh dari penelitian didapatkan hasil sampel sebanyak 19 subyek penelitian infeksi luka diabetik yang memenuhi kriteria dari 28 orang. Subyek penelitian paling banyak berjenis kelamin laki-laki, usia terbanyak 40-60 tahun (Gambar. 1). Lama diabetes terbanyak adalah $>10$ tahun, dan lama ulkus terbanyak adalah pada minggu 1-2 setelah terjadi luka yaitu sebesar $47,37 \%$.

Pasien laki-laki lebih banyak ditemukan dibandingkan dengan pasien perempuan dengan perbandingan 1: 1,71. Menurut Wells [8] jenis kelamin tidak termasuk dalam faktor resiko ulkus kaki diabetik, faktor resiko utama adalah faktor umur, lama menderita DM, kebiasaan dan gaya hidup. Persentase terbesar pasien ulkus kaki diabetik adalah pasien yang berusia 40-60 tahun, hasil ini berbeda dari usia pada teori Rochman yang menyatakan faktor terbesar luka diabetik adalah usia $\geq 60$ tahun. Ulkus diabetik pada usia $\geq 60$ tahun disebabkan oleh fungsi tubuh secara fisiologis menurun karena proses aging dan terjadi penurunan sekresi atau resistensi insulin. Usia juga mempengaruhi lama penyembuhan luka pada pasien ulkus kaki diabetik. Usia berhubungan dengan jumlah elastin yang menurun dan regenerasi kolagen yang berkurang akibat penurunan metabolisme sel.

Pasien dengan lama menderita DM terbanyak adalah $>10$ tahun, hasil ini didukung dengan teori Wells dan hasil penelitian Hastuti dimana faktor resiko ulkus diabetik adalah pasien yang menderita 
$\mathrm{DM}>$ dari 10 tahun. Lama diabetes ini terkait dengan kadar glukosa darah yang tidak terkendali akan menyebabkan komplikasi kronik yaitu neuropati, iskemik, dan angiopati dan dalam waktu beberapa lama akan menyebabkan kematian jaringan yang akan berkembang menjadi ulkus diabetik dan infeksi.

\section{PEMBAHASAN}

Pada penelitian ini jumlah terbesar adalah pasien datang setelah 1-2 minggu terjadi luka, hasil ini didukung dengan teori Misnadiarly dimana pasien dengan luka ulkus $>2$ minggu umumnya mempunyai infeksi luka yang lebih luas, ini juga terkait dengan pengetahuan pasien dalam membersihkan luka untuk mencegah infeksi dan terjadinya infeksi yang lebih luas. Tingkat keparahan kerusakan jaringan luka dan infeksi sangat dipengaruhi oleh deteksi dini keadaan luka dan infeksi serta penatalaksanaan luka yang tepat sehingga meminimalkan kerusakan jaringan yang lebih dalam.

\section{Ulkus kaki diabetik}

Keadaan infeksi terlihat jika terjadi radang, tanda pokok radang akut dapat dilihat pada pasien ulkus kaki diabetik seperti nyeri (dolor), kemerahan (rubor), panas (kalor), bengkak (tumor), dan gangguan

Tanda-tanda infeksi lain dapat diamati dari penilaian terhadap kondisi klinis pasien, temperatur tubuh $>37 \mathrm{oC}$ dan jumlah leukosit $>10.000 / \mu \mathrm{L}$. Pada penelitian ini subyek penelitian datang dalam keadaan demam yang merupakan manifestasi sistemik yang paling sering terjadi pada respon radang, demam manifestasi dari kebanyakan penyakit yang disebabkan oleh adanya infeksi. Pada penelitian ini pasien datang dengan pus positif, pus dihasilkan bila netrofil dan makrofag menelan sejumlah besar bakteri dan jaringan nekrotik. Subyek penelitian mengalami rasa nyeri (dolor) akibat regangan dan distorsi jaringan karena edema dan tekanan pus di dalam rongga abses.

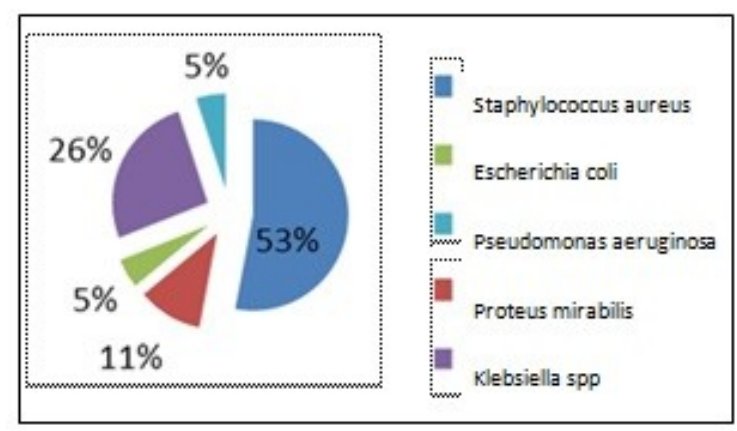

\section{Gambar 2. Persentase bakteri hasil pemeriksaan mikrobiologis}

Pada penelitian ini, pemeriksaan mikrobiologis dilakukan terhadap pus dari ulkus kaki semua subjek penelitian. Hasilnya menunjukkan bahwa Staphylococcus aureus merupakan jenis bakteri yang dominan (Gambar2).

Hasil ini sesuai dengan penelitian yang dilakukan oleh Hatanta. S. aureus yang memasuki jaringan melepaskan banyak sekali toksin yang mematikan sel-sel, akibatnya peradangan berlangsung jauh lebih cepat dari penggandaan dan penyebaran Staphylococcus itu sendiri.

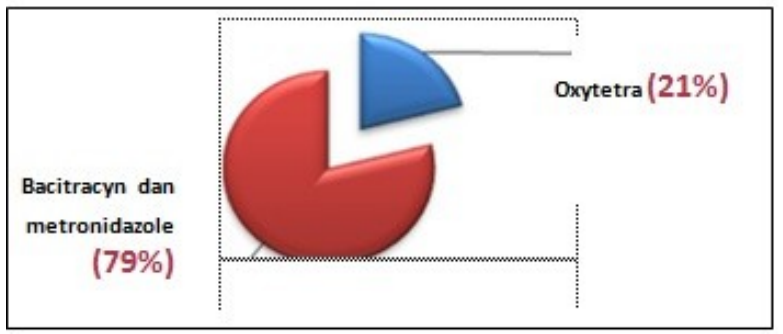

\section{Gambar 3. Penggunan Salep kulit secara empiris}

Subyek penelitian menggunakan Salep kulit lain secara empiris sebelum mendapatkan hasil pemeriksaan mikrobiologis (Gambar 3). Penggunaan Salep kulit lain dilanjutkan dengan pemilihan kulit yang sesuai dengan sensitifitas bakteri. Hasil penelitian ini didukung oleh hasil penelitian Noor dkk dimana untuk penanganan teori Frykberg dkk dimana pilihan terapi infeksi ulkus diabetik derajat sedang sampai berat yaitu 
ampisillin sulbaktam atau sefalosforin golongan 3 yang dikombinasi dengan metronidazol. Pilihan terapi lain untuk infeksi ulkus kaki diabetik sedang sampai berat yaitu amoksisilin klavulanat atau golongan floroquinolon yang dikombinasi dengan metronidazole. Kombinasi siprofloksasin dengan mekanisme kerja obat ini melalui penghambatan sintesis DNA, sehingga menyebabkan kematian sel. Kombinasi ini direkomendasikan khususnya pada kelompok pasien yang diduga terinfeksi bakteri $P$. aeruginosa, $K$. penumoniae dan Acinetobacter spp. Siprofloksasin diindikasikan pada pasien infeksi ulkus kaki diabetik untuk infeksi jaringan lunak, tendon, tulang dan infeksi yang disebabkan oleh bakteri yang banyak resisten terhadap antibiotik (multidrug-resistant/ MDR), seperti Pseudomonas spp.

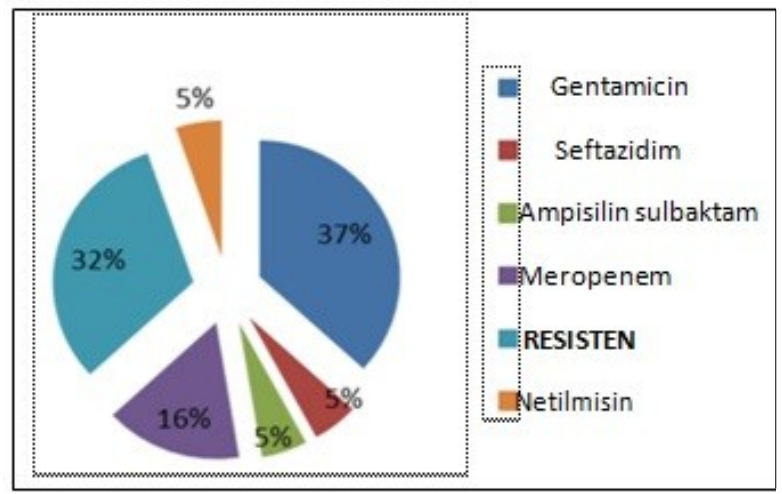

\section{Gambar 4. Sensitifitas bakteri terhadap Antibiotik}

Setelah hasil pemeriksaan mikrobiologi keluar antibiotik Gentamicin ditemukan masih sensitif terhadap bakteri patogen yaitu pada $36,8 \%$ subjek penelitian, sehingga pada pasien ini dilanjutkan terapi menggunakan antibiotik tersebut. Pada 63,2\% subjek penelitian lainnya dapat dilihat pada (Gambar 4).

Penggunaan antibiotik meropenem pada subjek penelitian sebesar 5,3\% dari $16 \%$. Subjek penelitian menggunakan antibiotik adalah pasien yang hasil mikrobiologinya sensitif meropenem. Pada penelitian ini ditemukan $5,3 \%$ subjek penelitian sensitif terhadap antibiotik netilmisin. Netilmisin bersifat nefroktoksik dan karena keadaan infeksi pertama yaitu penggunaan antibiotik secara empiris, untuk infeksi berat menggunakan antibiotik spektrum luas dan anaerob, menurut penelitian Mary dkk, pemilihan antibiotik empiris harus tepat karena Kesalahan pemilihan akan terkait dengan kejadiaan resistensi antibiotik.

Pada penelitian ini Salep kulit gentamicyn yang paling banyak digunakan (Gambar 3). Salep Gentamicyn adalah obat dengan fungsi untuk mencegah atau mengobati berbagai infeksi bakteri, Salep Kulit gentamicin termasuk golongan antibiotik aminoglikosida, obat ini bekerja dengan menghentikan bakteri. Penggunaan Salep Kulit Gentamicyn pada penelitian ini sesuai dengan

CKD (Chronic Kidney Disease) sehingga pasien ini melanjutkan penggunaan antibiotik secara empiris. Penggunaan antibiotik pada subjek penelitian dengan hasil kultur pus bakteri resisten terhadap antibiotik adalah berdasarkan studi empiris. Antibiotik meropenem pada penelitian ini sensitifitasnya masih tinggi, hasil ini sesuai dengan hasil penelitian Hatanta, Decroli dkk dan penelitian Kahuripan.

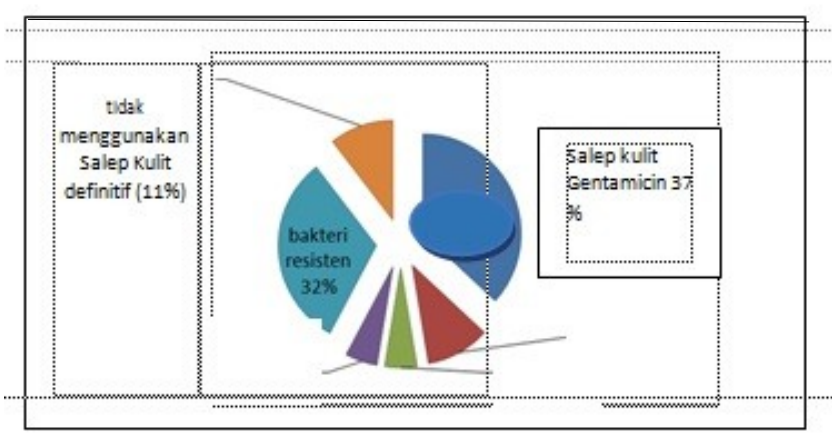

\section{Gambar 5. Penggunan Salep Kulit secara definitif}

Setelah hasil sensitifitas bakteri terhadap antibiotik diperoleh, hasil penggunaan Salep Kulit definitif pada subjek penelitian dapat dilihat pada Gambar 5. Salep Kulit Gentamicin adalah antibiotik yang paling 
banyak digunakan dan beberapa pasien tidak mendapatkan antibiotik secara definitif.

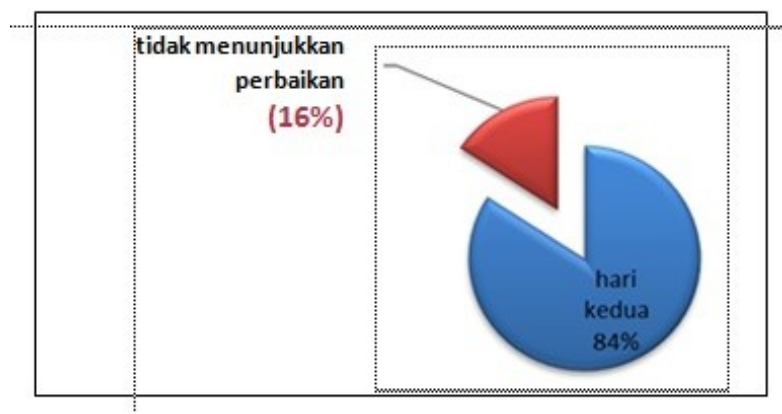

Gambar 6. Perbaikan leukosit

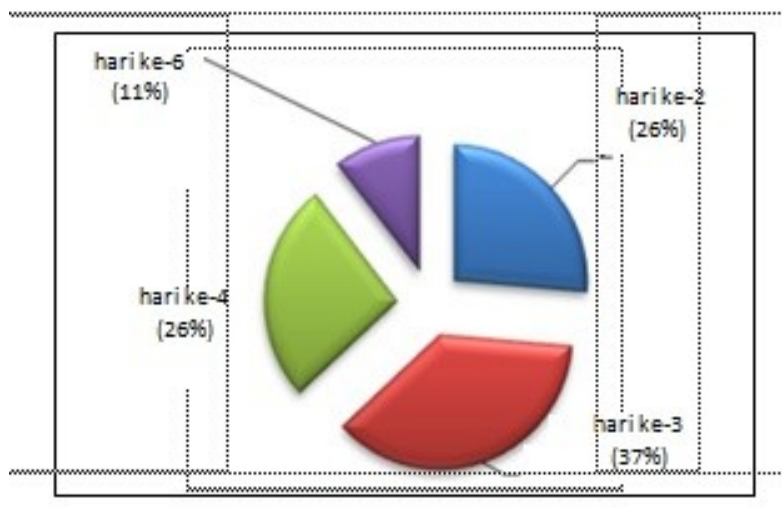

Gambar 7. Penurunan demam

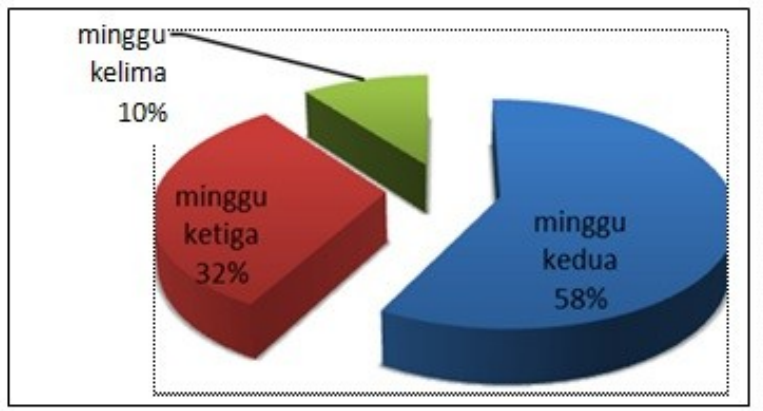

\section{Gambar 8. Perbaikan tanda-tanda inflamasi}

Berdasarkan penggunaan salep kulit antibiotik definitif 5 hari. Subjek penelitian ini didiagnosa dengan DM tipe 2 dengan ulkus dan anemia, memiliki riwayat DM besar dari 5 tahun, mempunyai bakteri patogen yang resisten terhadap antibiotik golongan sefalosporin diharapkan mencapai target terapi yang lebih luas dan efek kerja yang maksimal karena diperoleh hasil pengamatan terhadap penurunan leukosit, demam dan tanda inflamasi (Gambar 6, 7, dan 8). Menurut Permenkes, pemantauan respon terapi antbiotik dapat dilakukan dengan melihat respon klinis pasien, penurunan temperatur tubuh dan penurunan jumlah leukosit, untuk menguatkan hasil dapat dilakukan pemeriksaan mikrobiologi dengan hasil keberhasilan terapi yaitu tidak tampak kuman secara mikroskopis.

Pada penelitian ini subyek penelitian megalami respon peradangan (Gambar 8), respon peradangan tersebut diamati setelah penggunan antibiotik, hasil diperoleh pasien yang mengalami perbaikan terbanyak yaitu pada minggu kedua, hasil perbaikan inflamasi diikuti dengan adanya penurunan jumlah leukosit, karena menurunnya jumlah bakteri patogen dalam tubuh, dimana bakteri patogen adalah penyebab inflamasi. Salah satu tanda infeksi adalah dolor atau nyeri, pada beberapa subyek penelitian tidak mengalami nyeri ini dikarenakan keadaan neuropati pasien yang menyebabkan hilangnya sensasi protektif.

Pada penelitian ini ditemukan sebanyak $21,05 \%$ subjek penelitian yang penggunaan antibiotiknya tidak efektif dimana tidak memberikan respon perbaikan leukosit pada hari kedua sampai ketiga setelah pemberian antibiotik dan tidak menujukkan leukosit normal pada pemberian antibiotik selama 7 sampai 21 hari. Subjek penelitian menunjukkan penurunan demam lebih dari semua antibiotik yang diujikan secara mikrobiologi sehingga mendapatkan antibiotic secara empiris, mengalami trombositosis dan mengalami peningkatan LED. Pengelompokan subjek penelitian berdasarkan grade ulkus kaki diabetik yaitu 12 orang pasien ulkus dengan grade 1, 16 orang pasien ulkus dengan grade 2 .

Hasil ini sesuai dengan teori Wells dan penelitian Ahmad bahwa faktor usia, penyakit diabetes dan lamanya penyakit diabetes mempengaruhi keadaan infeksi ulkus kaki diabetik. Terapi infeksi ulkus kaki diabetik memerlukan durasi terapi 7 sampai 14 hari 
atau 21 hari. Efek dari antibiotik terhadap tanda-tanda infeksi pasien masih terdapat variasi antara pasien satu dengan pasien yang lainnya dikarenakan berbagai faktor sesuai dengan teori Wells faktor yang mempengaruhi seperti penggunanaan antibiotik, faktor adanya penyakit lain, faktor kebersihan ulkus kaki sehingga memudahkan untuk masuknya bakteri dari luar, faktor tingkat keparahan infeksi saat datang, dan faktor kondisi imunitas dan gizi pasien.

\section{KESIMPULAN}

Pemberian Salep Kulit Gentamicyn untuk infeksi ulkus kaki diabetik Grade I dan II pada penelitian ini dilakukan secara empiris terhadap $42,10 \%$ dan secara definitif terhadap 57,89\%. Salep Kulit Gentamicyn efektif terhadap 78,94\% subjek penelitian yaitu dapat memberikan respon pada leukosit, tanda infeksi dan parameter demam seteleh pemberian Salep Kulit Gentamicyn 3-5 hari dan hasil terapi maksimal pada hari ke 7 sampai 21 setelah pemberian Salep Kulit Gentamicyn. Salep Kulit Gentamicyn tidak efektif terhadap $21,05 \%$ orang subyek penelitian dengan bakteri resisten terhadap semua jenis Salep Kulit.

\section{SARAN}

Kepada peneliti selanjutnya diharapkan agar berupaya lebih mengembangkan dan memperdalam bahasan tentang efektifitas pemberian salep kulit gentamicyn terhadap penyembuhan luka pada pasien diabetes mellitus dengan menggunakan desain penelitian yang berbeda.

\section{DAFTAR PUSTAKA}

Ahmad, J. (2016). The Diabetic Food. Diabetes \&

Metabolic Syndrome: Clinical research $\&$ reviews, 10(1), 48-60.

Brand, P. (2000). The foot in diabetic. Diabetes Mellitus.
ADA. Premtice hal International. Maryland.

Brunton, L., Keith., \& Donald, L. (2010). Goodman \& Gillman's Manual of Pharmacology and Therapeutics. Diterjemahkan oleh July Manurung. ECG. Jakarta.

Decroli, E., Jazil, K., Asman, M., \& Syafril, S. (2008). Profil

Ulkus Diabetik Pada Penderita Rawat Inap Bagian Penyakit Dalam

RSUP Dr. M. Djamil Padang. Majalah Kedokteran Indonesia, 58(1), $1-7$.

Dipiro, J., Robert, L., Gary, C., \& Barbara, G. (2006). Pharmacotherapy: A Pathophysiologic Approach. Sixth Edition. The McGraw-Hill Companies. Inc.

Frieri, M., Kumar, K., Boutin, A. (2017). Antibiotic Resistance. Jurnal of Infection and Public Health, 10(4), 369-378.

Frykberb, R. (2002). Risk Factor, Pathogenesis and Management

Of Diabetic Foot Ulcers. Des Moines University. Lowa.

Frykberg, R., Zgonis, T., \& David, G. (2006). Diabetic Foot Disorders a Clinical Practice Guideline, An official publication of the American College of Foot and Ankle Surgeons. USA.

Guyton, A., \& Hall, J. (2012). Buku Ajar Fisiologi Kedokteran. Edisi 11. Alih bahasa Irawati dkk. EGC. Jakarta.

Goldman, D., \& Huskins, W. (2000). Control of Nosocomial Antimicrobial Resistant Bacteria: Strategy Priority, Clinical Infectious Disease. New York.

Hatanta, A. (2013). Kajian Penggunaan Antibiotik Pada Pasien Infeksi Ulkus Kaki Diabetik IRNA PD RSUP Dr. M. Djamil Padang. (Tesis). Universitas Andalas. Padang.

Hastuti, Rini, T. (2007). Faktor-faktor Risiko Ulkus Diabetika pada Penderita Diabetes Millitus (Studi kasus di RSUD Dr. Moewardi Surakarta). (Tesis). Universitas Diponegoro. Semarang. Hospital Medicine Clinics, 1(2), e185-e198 
Kahuripan, A., Retnosari, A. (2009). Analisis pemberian antibiotik berdasarkan hasil uji sensitifitas terhadap pencapaian clinical outcome pasien infeksi ulkus diabetik di RSUD Dr. H. Abdul Moeloek Lampung. Majalah Ilmu Kefarmasian, 6(2), 75-87.

Katzung, B., Susan, B., Masters., \& Anthony, J. (2010). Basic $\square$ Clinical

Mary, T., Alicia, T. \& Adolf, W. K. (2012). Diabetic Foot Infection.

Misnadiarly. (2006). Diabetes Mellitus Gangren, Ulcer, Infeksi.Penerbit Populer Obor. Jakarta.

Noor, S., Rizwan, U. K. \& Jamal, A. (2017). Understanding Diabetic Foot Infection and its Management. Diabetes \& Metabolic Sindrome: Clinical Research \& Reviews, 11(2), 149-156.

Permenkes. (2011). Pedoman Umum Penggunaan Anti biotik.Kementrian Kesehatan RI. Jakarta.

Pharmacologiy 10th ed. McGraw-Hill Companies. USA.

Rochman, W. (2009). Diabetes Millitus pada Usia Lanjut. Jilid III. Edisi kelima. Balai Penerbit FK UI. Jakarta.

Wells, B., Dipiro, J., \& Terry, L. (2009). Pharmacotherapy Handbook, Seventh Edition. The McGraw-Hill Companies. Inc. New York. 